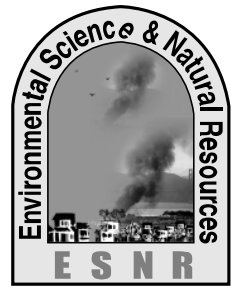

J. Environ. Sci. \& Natural Resources, 5(2): 161 - 166, 2012

ISSN 1999-7361

\title{
Community Based Risk Assessment and Adaptation to Climate Change in Dharam Wetland under Sunamganj District
}

\author{
K. M. Bahauddin ${ }^{1}$ and M. H. Uddin ${ }^{2}$ \\ ${ }^{1}$ Department of Environmental Sciences, Jahangirnagar University,Bangladesh \\ ${ }^{2}$ MATS, Faridpur
}

\begin{abstract}
This study presented community based framework to assess the risk and the adaptation practice as response to climate change and different disasters. The community's experience suggested risks are shifting along with prolongation of hydro-meteorological events and its irregularity is threatening adaptation capacities as it is affecting the sensitivity and production of the ecosystem of the region. In this study, community identified flash flood, flood, wave erosion; river bank erosion and water pollution were as common hazards and risks of their life as well as community identified and assessed their seasonal calendar and livelihood activities, element at risk, problem matrix ranking/ priority, risk evaluation, causes of risks and their adaptation. In this viewpoint, some recommendations were suggested for community to adaptation, practices and conservation of wetland.
\end{abstract}

Key words: Adaptation, Community Based Risk Assessment, Disaster, Hazard, Risk

\section{Introduction}

Bangladesh possesses enormous area of wetlands including rivers and streams, freshwater lakes and marshes, haors, baors, beels, water storage reservoirs, fish ponds, flooded cultivated fields and estuarine systems with extensive mangrove swamps. Wetland system of Bangladesh is being affected by the anomalous of climate change along with other Ramser Sites of Bangladesh. Bangladesh is at great risk under global climate change. So the risk assessment and adaptation process is needed for achieving the sustainable development, as it introduce an additional layer of complexity and uncertainty into management planning. Moreover wetland system has immense importance on the livelihood of the people not only in Bangladesh but also around the world as it cover $6 \%$ of the world's land surface and contain about $12 \%$ of the global carbon pool, playing an important role in the global carbon cycle.

The initial approach to adaptation was dominated by the top-down approach derived from the original characterization of the issue as a global environmental pollution problem. The best-known formulation is to be found in the IPCC Technical Guidelines for Assessing Climate Change Impacts and Adaptations.

Some of the methods can be adapted for use in determining community-based adaptation to climate change and Community Based Risk Assessment which has received increased attention in the scientific and policy debate, and is seen as complementary to mitigation. As all the communities are not same and different communities can have differential risks which are scale depended, for this requirement tools like Community Based Risk assessment taken for planning adaptation strategy.

Drawing from the literatures on recent climate change impacts and vulnerability, the purpose of this study is twofold; firstly, it provides an evidence of changes through the risk assessment and responses in this area that are identified as adaptation practice, and secondly, the vulnerability assessment provides information on the susceptibilities resulting from climate change and available adaptation options.

\section{Methodology}

\section{Operational definition of Community Based Risk} Assessment

Community risk assessment refers to participatory methods to assess local hazard, risk, and vulnerability, capacity to cope and finally explore the options to reduce potential risks to be adopted by community at risk. The purpose of a community risk assessment is to guide practical steps in preparedness and mitigation that reduce both the chance of emergencies and the consequences when they cannot be avoided.

\section{Selection of the Study Area}

Dharam haor is situated in Dharmopasha upazilla with an area of $496.03 \mathrm{sq} \mathrm{km}$, is bounded by Meghalaya state on the north, Mohanganj and Barhatta upazilas on the south, Tahirpur and Jamalganj upazilas on the east, Kalmakanda and Barhatta upazilas on the west. This upazilla is under the Sunamganj district. The occupations of most of the people of this upazilla are agriculture and fishing. Major resources of this haor include fisheries and crop production.

\section{Data Collection and Analysis}

A number of tools were used to collect the information from community level such as focus group discussion, Key informant interview and 
Community consultation. The number of total respondents was 105 who were selected by random sampling method.

\section{Results and Discussion}

\section{Hazard Venn diagram}

Hazard Venn diagram allows participants to identify and analyze the common hazards that take place locally, their magnitude and likelihood. The study reveals that the community perceptions of common risks around the year are mostly related to hydrometeorological phenomena. The community's experience suggested that the main risks persisting are that of the shifting of period of occurrences of hydrometeorological events over the year which are, at the same time, expanding by length. This means communities are facing variable risk events for longer and unusual time which is ultimately threatening their adaptation capacities.

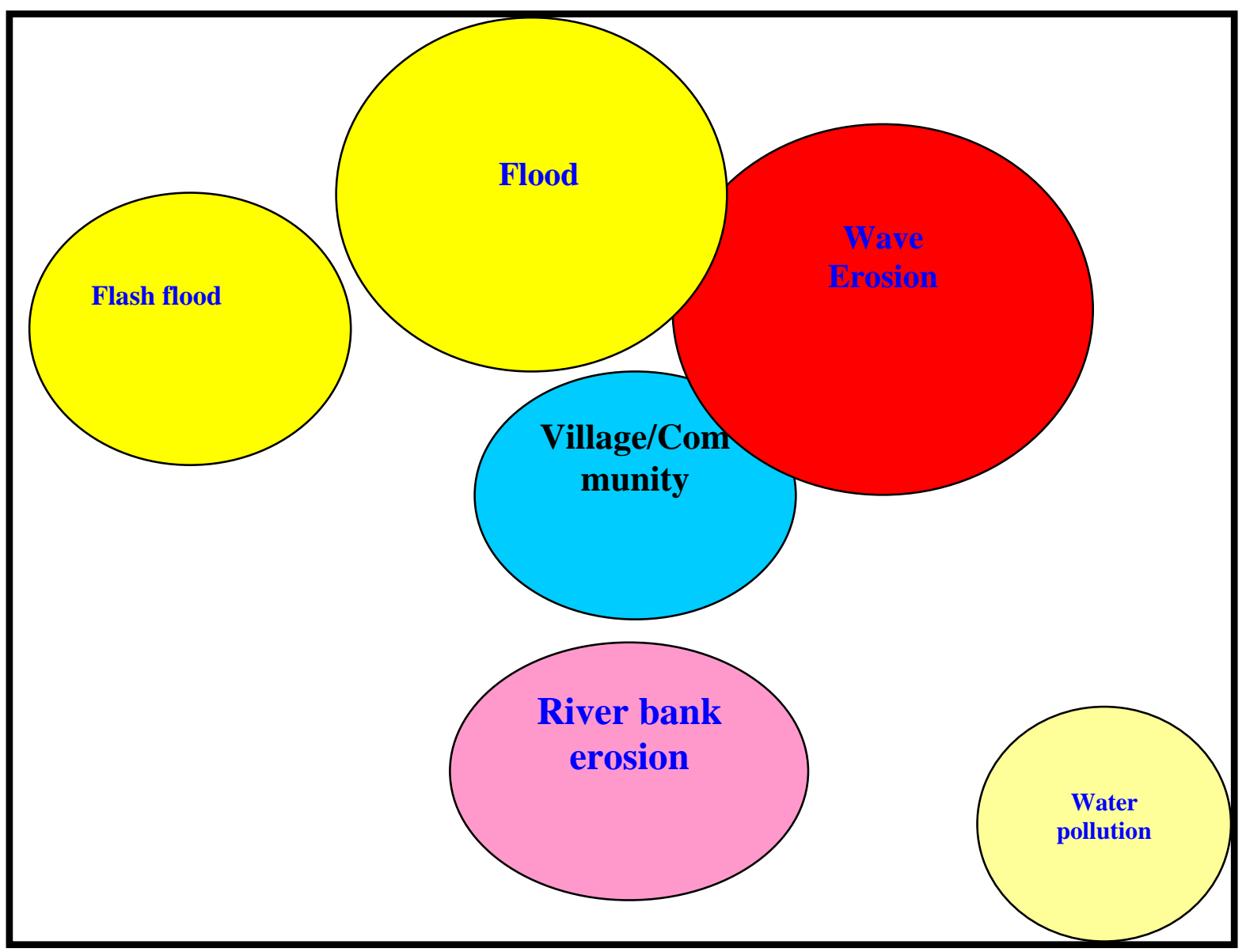

Fig 1: Community Hazard Venn diagram

From above figure, it showed that flood, wave erosion and flash flood were the major hazards in community livelihood as well as it also can be said that water pollution was one of minor problems that community is facing which evolved from different agricultural activities.

\section{Seasonal Calendar and Livelihood Activities}

Seasonal calendar and livelihood activities tracks seasonal changes, climate-related and other hazards, community events and activities related to a specific month. In the agricultural sector, this is used primarily to plot seasonal farm activities. 
Table 1: Community seasonal calendar and livelihood activities

\begin{tabular}{|c|c|c|c|c|c|c|c|c|c|c|c|c|}
\hline Livelihood Activities & 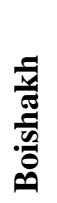 & 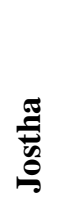 & $\frac{\bar{\pi}}{\frac{\pi}{2}}$ & 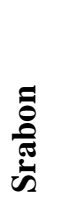 & 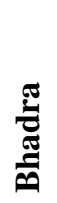 & 清 & 先 & 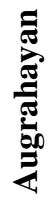 & $\begin{array}{l}\frac{n}{0} \\
\overline{0} \\
0\end{array}$ & $\begin{array}{l}\text { 芴 } \\
\sum^{\sigma}\end{array}$ & $\frac{\Xi}{E_{0}^{0}}$ & \\
\hline \multicolumn{13}{|l|}{ Rice (Aman) harvesting } \\
\hline \multicolumn{13}{|l|}{ Rice (Boro) harvesting } \\
\hline \multicolumn{13}{|l|}{ Vegetable farming } \\
\hline \multicolumn{13}{|l|}{ Fish capture } \\
\hline \multirow{2}{*}{\multicolumn{13}{|c|}{$\begin{array}{l}\text { Duck rearing } \\
\text { Hazards }\end{array}$}} \\
\hline & & & & & & & & & & & & \\
\hline \multicolumn{13}{|l|}{ Flash flood } \\
\hline \multicolumn{13}{|l|}{ Flood } \\
\hline \multicolumn{13}{|l|}{ Wave erosion } \\
\hline \multicolumn{13}{|l|}{ River bank erosion } \\
\hline \multicolumn{13}{|l|}{ Road submerged by flood } \\
\hline Water pollution & & & & & & & & & & & & \\
\hline
\end{tabular}

\section{Element at Risk}

In this study, community risk is considered the combination of an event, the likelihood that it will happen and its consequences and hazard is identified by community as event or physical condition that has the potential to cause fatalities, injuries, property damage, infrastructure damage, agricultural loss, damage to the environment, interruption of business or other types of harm or loss. Climate and other risk identification have three basic elements: probability, exposure and consequences. Each risk can be identified by its own natural characteristics, including geographic area (areal extent), time of year it is most likely to occur and its severity. In most cases, an extreme event may create multiple hazards: wind is a factor in thunderstorms and severe thunderstorms spawn tornados. Thus, it is necessary to identify the potential primary hazard but also its triggering effect on secondary hazards. Knowledge of the nature of risks, their geographic coverage and their potential future behaviour is fundamental for designing a viable adaptation practice to reduce the impact of climate change in the agriculture sector.

Table 2: Element at risk with hazards

\begin{tabular}{|c|l|c|c|c|c|c|}
\hline \multirow{2}{*}{$\begin{array}{c}\text { Risk } \\
\text { area }\end{array}$} & \multicolumn{2}{|c|}{ Elements } & \multicolumn{3}{c|}{ Hazard } \\
\hline & Flood & Flash flood & $\begin{array}{l}\text { Wave } \\
\text { erosion }\end{array}$ & $\begin{array}{l}\text { River bank } \\
\text { erosion }\end{array}$ & $\begin{array}{l}\text { Heavy } \\
\text { rainfall }\end{array}$ \\
\hline \multirow{5}{*}{ Agricultural } & Aman Paddy & $\checkmark$ & & & & $\checkmark$ \\
\hline & Boro Paddy & & $\checkmark$ & & & \\
\hline & Vegetable & $\checkmark$ & $\checkmark$ & & & $\checkmark$ \\
\hline & Paddy seedbed & & $\checkmark$ & & & $\checkmark$ \\
\hline & Livestock & $\checkmark$ & & & & \\
\hline & Poultry & $\checkmark$ & & & & \\
\hline \multirow{5}{*}{ Infrastructure } & House & $\checkmark$ & & $\checkmark$ & $\checkmark$ & \\
\hline & Road & $\checkmark$ & & $\checkmark$ & $\checkmark$ & \\
\hline & School ground & $\checkmark$ & & $\checkmark$ & & \\
\hline & Tube well & $\checkmark$ & & & & \\
\hline
\end{tabular}

From above table it showed that areas such as agriculture and infrastructure were faced hazards like flood and flash flood majorly. These areas were also faced hazards like wave erosion, river bank erosion and heavy rainfall as well. 


\section{Problem Matrix Ranking/ Priority}

In this study matrix ranking prioritized climate and other risks, needs and options and ranking/ prioritized the analyses problems in order to rate community priorities or the significant problems faced by the community. In table 3 , community ranked/ prioritized the problems as below

Table 3: Community Problem Matrix Ranking/ Priority

\begin{tabular}{|l|c|}
\hline \multicolumn{1}{|c|}{ Problem } & Rank/ Priority \\
\hline Flash Flood & 4 \\
\hline Flood & 2 \\
\hline Wave Erosion & 1 \\
\hline River bank erosion & 3 \\
\hline
\end{tabular}

Table 3 shows that communities have identified some physical and meteorological causes behind such changes. According to the community conceived knowledge of hydro-meteorological phenomena that are affecting their livelihoods. Trends of livelihoods and climate change impact shows that dependency of the communities on paddy, fishery and livestock has been reduced with the course of time. The problem matrix, seasonal calendar and the case studies developed by the communities suggest the climate change might have triggered the changes of livelihoods pattern in the region through the influences of the hydo-meteorological events. People are migrating into small business, stationary shops, rickshaw puller, and day labor as their alternative livelihood and the rate of these changes have gained pace in the recent years. And in such cases, local adaptation practices are almost absent in the region except applying more incentive in compensating such as rising cost of production of paddy by applying manifold chemical fertilizer and pesticide, expensive diesel-driven ground water irrigation, biodiversity destroying shrimp culture etc.

\section{Risk Evaluation}

Risk evaluation referred determination of risk management priorities through establishment of qualitative and/or quantitative relationships between benefits and associated risks. Community measured the risks as its effect, consequences, probability and their acceptance level. Community evaluated the risks based on tentative effect, measure of effect, likelihood, measure of risk and its acceptability which showed in table 4

Table 4: Community risk evaluation

\begin{tabular}{|l|l|l|l|l|l|}
\hline Risks & $\begin{array}{l}\text { Tentative } \\
\text { effect }\end{array}$ & $\begin{array}{l}\text { Measure } \\
\text { of effect }\end{array}$ & Likelihood & $\begin{array}{l}\text { Measure } \\
\text { of risk }\end{array}$ & $\begin{array}{l}\text { Acceptanc } \\
\text { e level }\end{array}$ \\
\hline $\begin{array}{l}\text { If heavy rainfall occurred, significant number } \\
\text { of houses will be submerged / damaged. }\end{array}$ & $\begin{array}{l}\text { Damaged } \\
\text { the House/ } \\
\text { Yard }\end{array}$ & High & Each year & High & $\begin{array}{l}\text { Not } \\
\text { Acceptable }\end{array}$ \\
\hline $\begin{array}{l}\text { If flood occurred, houses, school, } \\
\text { connecting road, Bazaar will be submerged/ } \\
\text { damaged }\end{array}$ & $\begin{array}{l}\text { Damaged / } \\
\text { submerged }\end{array}$ & High & $\begin{array}{l}\text { Every 3-4 } \\
\text { years } \\
\text { interval }\end{array}$ & High & $\begin{array}{l}\text { Not } \\
\text { Acceptable }\end{array}$ \\
\hline $\begin{array}{l}\text { Due to river bank erosion, significant } \\
\text { number of houses and other infrastructure } \\
\text { will be damaged }\end{array}$ & Damaged & High & Each year & High & $\begin{array}{l}\text { Not } \\
\text { Acceptable }\end{array}$ \\
\hline $\begin{array}{l}\text { If flash flood occurred, agriculture land and } \\
\text { fisheries will be destroyed }\end{array}$ & Damaged & High & $\begin{array}{l}\text { Mostly } \\
\text { each year }\end{array}$ & High & $\begin{array}{l}\text { Not } \\
\text { Acceptable }\end{array}$ \\
\hline $\begin{array}{l}\text { For water pollution, different diseases will be } \\
\text { evolved }\end{array}$ & $\begin{array}{l}\text { Different } \\
\text { diseases }\end{array}$ & Medium & Each year & low & Acceptable \\
\hline
\end{tabular}

\section{Cause Analysis of Risks and Adaptation}

In this method, repondents of this study identified the causes of risks, its adaptation measures and reported strategy 
Table 5: Cause analysis of risks and adaptation at community level

\begin{tabular}{|c|c|c|c|}
\hline Risk & Causes & $\begin{array}{l}\text { Option of risk reduce/ } \\
\text { adaptation }\end{array}$ & Timeline \\
\hline $\begin{array}{l}\text { If heavy rainfall occurred, significant } \\
\text { number of houses will be submerged / } \\
\text { damaged. }\end{array}$ & $\begin{array}{l}\text { Heavy Rainfall/Strom } \\
\text { Water flow from haor } \\
\text { River wave }\end{array}$ & $\begin{array}{l}\text { Tree plantation beside } \\
\text { homestead } \\
\text { Home stead raising } \\
\text { Protection by local } \\
\text { mechanism }\end{array}$ & Long term \\
\hline $\begin{array}{l}\text { If flood occurred, houses, school, } \\
\text { connecting road, Bazaar will be } \\
\text { submerged/ damaged }\end{array}$ & $\begin{array}{l}\text { Heavy Rainfall } \\
\text { Overflow of river water }\end{array}$ & $\begin{array}{l}\text { Flood Protection dike } \\
\text { Mount/ school field/ } \\
\text { connecting road raising }\end{array}$ & $\begin{array}{l}\text { Short/long } \\
\text { term }\end{array}$ \\
\hline $\begin{array}{l}\text { Due to river bank erosion, significant } \\
\text { number of houses and other } \\
\text { infrastructure will be damaged }\end{array}$ & $\begin{array}{l}\text { Current } \\
\text { Wave }\end{array}$ & $\begin{array}{l}\text { Concrete Block set up } \\
\text { River dredging }\end{array}$ & $\begin{array}{l}\text { Short/long } \\
\text { term }\end{array}$ \\
\hline $\begin{array}{l}\text { If flash flood occurred, agriculture land } \\
\text { and fisheries will be destroyed }\end{array}$ & $\begin{array}{l}\text { Heavy Rainfall/Strom } \\
\text { Water from Hill }\end{array}$ & $\begin{array}{l}\text { River dredging } \\
\text { Raise dike of embankment } \\
\text { Early variety rice cultivation }\end{array}$ & $\begin{array}{l}\text { Short/ mid } \\
\text { term }\end{array}$ \\
\hline $\begin{array}{l}\text { For water pollution, different diseases } \\
\text { will be evolved }\end{array}$ & $\begin{array}{l}\text { Not available tube well } \\
\text { Not available Sanitary } \\
\text { latrine }\end{array}$ & $\begin{array}{l}\text { Hand tube well set up } \\
\text { Sanitary latrine set up }\end{array}$ & Long term \\
\hline
\end{tabular}

\section{Recommendations}

Based on the findings, the study leads towards the following recommendations

- Small dams: It can be used to reestablish or create wetland hydrology. Small earthen dams can be built at very low costs using standard farming equipments.

- Backfilling canals: It can be lead to at least partial restoration of wetlands impacted by canal construction.

- Control of impact of feral fish: Uses natural processes to restore wetland biodiversity; quick local responses in wetland health are visible to community and funding bodies.

- Crevasse splays: Inexpensive method of restoring wetland in subsiding deltas.

- Dredged material: It provides an alternate method of disposing and existing environmental benefits.

- Excavation: Allows creation of wetlands at a number of locations.

- Removing culverts: It can result in immediate reestablishment of tidal flushing with subsequent rapid changes in vegetation and faunal communities. In some cases, improved flushing can reduce mosquito populations.

- Terracing: It may lead to recover of vegetated emergent marsh habitat or establishment of submerged aquatic vegetation within terrace cells.

- Weed control: It can allow re-establishment of native plant communities.

\section{Approaches for Wetland Conservation}

- Recognizing that climate change may substantially affect the ecological character of wetlands and their sustainable use, and aware of the potentially important role of wetlands in adapting to and in mitigating climate change.

- River management systems, such as levees and flow diversions, have reduced river-pulsed floods and the delivery of sediment to delta wetlands, decreasing their ability to form soil and raise elevation.

- Dredging of river beds combats increased sedimentation, thereby improving navigability.

- High bank of pond and or using nets around the pond.

- Increasing vegetative coverage along river banks protects against erosion resulting from increased flow and flooding.

- Protection and regeneration of the swamp forest in the haor ecosystem.

- Establishment of fish sanctuary, priority will be given to the fish breeding grounds and harvesting on the breeding season, usually it is early monsoon in haor and mid monsoon in beel basin.

- Protection of reed lands and swamp forest.

- Legislation to prevent eutrophication: established standards for agricultural, industrial, and household water sources.

- Ordinance for the conservation of Reed vegetation zones: reeds play an important role in purifying water as well as providing habitat for birds and fish. 
- Ensuring participation of poor in planning phase: some of the recent initiatives used Participatory Action Plan Development as a consensus building tool among stakeholders. It will helpe the stakeholders to find a win -win solution of an ought to arise conflict prior to implementation.

\section{Conclusion}

The scenario is alarming because it suggests the lack of application of indigenous knowledge and local knowledge, short of local innovation initiatives, lack of adaptation capacities, absence of knowledge sharing and lack of understanding. These ultimately set these communities to severe vulnerability under the future climate change. Immediate attention, therefore, is to be put by the government on the issues and there are further researches to be undertaken to understand the nature of community adaptation and perception of climate change in the wetlands of Bangladesh if we want to stride forward to negotiate climate change in the country.

\section{References}

IPCC, “Climate change 2001,Impacts, adaptation, and vulnerability", Contribution of Working Group II to the third assessment report of the Intergovernmental Panel on Climate Change. Cambridge University Press, New York, $1032 \mathrm{pp}$.

IPCC, 1996, An Assessment of the Intergovernmental Panel on Climate Change, Intergovernmental Panel on Climate Change (IPCC), Cambridge University Press, New York.

Katrina M. Allen, 2006, Community-based disaster preparedness and climate adaptation: local capacity building in the Philippines, Blackwell Publishing. Disasters, 81-101 pp

Hossain, M. S. 2010. Wetland and Climate Change Adaptation", Ulashi Sreejony Sangha (USS) and Action Aid Bangladesh. ISBN 978-984-33-1676-9.

Sultana, P. and Thomson, P. 2004, Methods of consensus building for community- based fisheries management in Bangladesh and the Mekong Delta, Agricultural Systems, 327$353 \mathrm{pp}$. 